\title{
TORT INTERACTING WITH REGULATORY LAW
}

\section{Ben Pontin, Lecturer in Law, University of the West of England}

This article explores a number of issues relevant to the relationship between tort and regulatory law. ${ }^{1}$ The enormous recent interest in this topic, ${ }^{2}$ and the increasingly 'ritual' inquiry into the relationship between private and public law generally, ${ }^{3}$ prompts the question: 'why now the attention after years of neglect?' This is addressed in the opening section of the analysis, as a standpoint from which to reflect on in subsequent sections: the limitations of using tort as a regulatory device, what an awareness of tort adds to discussions of regulation and, perhaps most fundamental, how tort and regulatory law do and should interact. In addressing these issues, it is hoped to contribute to the development of a broader theoretical framework within which to appreciate current doctrinal controversies in the field, having regard to economic and other more overtly normative analyses. The doctrinal intricacies themselves are not the principal point of focus.

\section{A TRADITION OF DISENGAGEMENT FROM THE CONTEXT THAT TORT AND REGULATORY LAW PROVIDE FOR EACH OTHER}

Scholarship has been curiously selective in its treatment of the context that tort and regulatory law provide for each other. From a doctrinal perspective, for example, it is apparent that sustained attention has been given to the specific question of the actionability of a breach of statutory duty: Pound, ${ }^{4}$ Williams, ${ }^{5}$ Traynor, ${ }^{6}$ Stanton, ${ }^{7}$ and most recently Bennion, ${ }^{8}$ have all reflected in some depth on this aspect of the theme in hand. By contrast, however,

* With many thanks to Tim Jewell and Jenny Steele for comments on an earlier draft.

1 'Regulatory law' is often used interchangeably with the 'law of regulation' to connote legislation of a public law character: A I Ogus, "Economics, Liberty and the Common Law" (1980) 15 Journal for the Society of Public Teachers of Law 44, 57. See also G Teubner, 'After Legal Instrumentalism? Strategic Models of Postregulatory Law' in Teubner (ed), Dilemmas of Law in the Welfare State (Berlin, 1988), p 305.

2 Perhaps most notably in the context of tort's intersection with environmental regulation: J Steele, "Private Law and the Environment: Nuisance in Context" (1995) Legal Studies 236; "Assessing the Past" in Jewell and Steele (eds), Law in Environmental Decision-Making (Oxford, 1998). See too the commentary concerning public authority liability in negligence, below n 10 .

3 G Teubner, "After Privatization? The Many Autonomies of Private Law" (1998) 51 Current Legal Problems 393, 394.

4 R Pound, "Common Law and Legislation" (1908) 21 Harvard Law Review 383.

5 G Williams, "The Effects of Penal Legislation in the Law of Tort" (1960) 23 MLR 233.

6 R Traynor, "Statutes Revolving in Common-Law Orbits" (1968) 17 Catholic University of America Law Review 401.

7 Stanton, Breach of Statutory Duty in Tort (London, 1986)

8 F Bennion, "Codifying the Tort of Breach of Statutory Duty" (1996) 17 Statute Law Review 192. 
related areas of equal importance have tended to attract comparatively less interest. This is particularly true of nuisance in the context of regulatory powers. ${ }^{9}$ It is also true, although perhaps to a lesser extent, of negligence. ${ }^{10}$ In this way, then, scholarship has failed to anticipate the rich variety of doctrinal influences emanating from within the wider regulatory context, which are illustrated well by the following cases involving nuisance and negligence: Cambridge Water Company v Eastern Counties Leather, ${ }^{11}$ where regulatory standards prescribed by the European Community were central to the definition of actionable damage; ${ }^{12}$ Gillingham Borough Council v Medway (Chatham) Dock Company, ${ }^{13}$ where local planning authority consent to develop land was held to be capable of altering the character of the neighbourhood within which actionability fell to be determined; ${ }^{14}$ Margereson and Hancock $\mathrm{v} J W$ Roberts, ${ }^{15}$ where occupational health and safety legislation concerning asbestos control played an important part in establishing a common law duty of care beyond the workplace, to encompass residents in the neighbourhood of the defendant company; and $X \mathrm{v}$ Bedfordshire County Council, ${ }^{16}$ where the question of the existence of a common law duty of care owing by local authorities was held to be

9 See eg the dismissal of the academic significance of the defence of statutory authority in Brazier, Street on Torts, ( $7^{\text {th }}$ ed, 1983): “The cases on this defence are very numerous but since they turn on the interpretation of. . . particular statutes and merely illustrate the general principle set out in the text [it is] unprofitable to discuss them" ( $\mathrm{p} 85, \mathrm{n}$ 7). A more sympathetic treatment of the doctrinal complexity of the subject is given in A Linden, "Strict Liability, Nuisance and Legislative Authorization" (1966) 4 Osgoode Hall Law Journal 197.

10 Cf P Craig, "Negligence in the Exercise of a Statutory Power" (1978) 94 LQR 428; and P Weir, "Government Liability" [1989] Public Law 40. More recently, there has been a noticeable proliferation of commentary on negligence in the exercise of statutory powers: eg R A Buckley, "Negligence in the Public Sphere: Is Clarity Possible?" (2000) 51 NILQ 25; S Bailey and M Bowman, "Public Authority Negligence Revisited" (2000) 59 Cambridge Law Review 85. A Commonwealth perspective is provided by J Doyle and J Redwood, "The Common Law Liability of Public Authorities: The Interface Between Public and Private law" (1999) 7 Tort Law Review 30. This literature is a response to the evolution of duty of care principles in $X$ v Bedfordshire County Council [1995] 2 AC 632, Stovin v Wise [1996] AC 923 and Barrett v Enfield LBC [1999] 3 WLR 79. For a different slant on the negligence/regulatory law theme see Margereson and Hancock $\mathrm{v} J W$ Roberts (October 27 1995, High Court; appeal dismissed, April 21996 (CA)), in which the Asbestos Industry Regulations 1931 played an important part in the court's findings on reasonable foreseeability. This is discussed insightfully in J Steele and N Wikeley, "Dust on the Streets and Liability for Environmental Cancers" (1997) 60 MLR 265, 266.

11 [1994] 2 AC 264.

12 See in a similar vein Blue Circle Cement v Ministry of Defence (ChD, 26 November 1996, unreported).

13 [1993] QB 343.

14 This was followed in Wheeler v Saunders [1995] 2 All ER 697 (CA), and Hunter v Canary Wharf [1996] 2 WLR 348 (CA).

15 Above $\mathrm{n} 10$.

16 Ibid. 
"profoundly influenced by the statutory framework within which the acts complained of were done." 17

Much the same can be said of legal historical scholarship. A well-known body of writing has centred on the evolution of tort during the industrial revolution and, in particular, the context that it provided for the emergence of modern regulatory laws. ${ }^{18}$ However, for the most part this depicts tort as an inexorably diminishing force, in the process of being superseded by modern regulatory forms. ${ }^{19}$ It is associated variously with a market which failed; ${ }^{20}$ or a private interest anachronism which came to be replaced by public welfare instruments aimed at "the socialisation of the activities of the people". ${ }^{21}$ This gives the impression of the Victorian era as one that presided over the abdication by private law of its responsibility for the legal regulation of social activities. ${ }^{22}$ One notable exception in this regard is provided by Bartrip and Burman, whose study of nineteenth century occupational health and safety law highlights the sense in which tort and regulatory law were not alternatives, but mutually reinforcing fields of law that interacted. ${ }^{23}$ It is only recently, however, that other regulatory settings, suggesting a far broader phenomenon, have begun to be appreciated in this connection. ${ }^{24}$

Similar comments can be directed at scholarship which takes as its subjectmatter contemporary regulatory law. For example Anthony Ogus, in his important (and largely economic) analysis of regulation, ${ }^{25}$ understands common law tort in terms of its being a wholesale alternative to collective regulatory forms. ${ }^{26}$ Likewise, in an earlier work, in which Ogus argues forcefully for a reversal of the academic bias away from common law towards the more salient law of regulation, ${ }^{27}$ the two are depicted as mutually exclusive. Readers are left pondering a choice between "either [a] decentralised common law approach, or [a] centralised regulatory

17 Ibid, at 739. See too Stovin v Wise and Barrett v Enfield CC (above n 10); and also Capital Counties v Hampshire CC [1997] 3 WLR 331 (CA), which addresses the policy factors that operate in this context (see further below, n 104). For an example of European Convention on Human Rights jurisprudence in this context, see Osman v UK (2000) 29 EHRR 245 - a controversial judgment of the European Court of Human Rights concerning Article 6 of the Convention (discussed in Bowman and Bailey (above $\mathrm{n}$ 10, 124-125)).

18 Most notable is J McLaren, "Nuisance Law and the Industrial Revolution - Some Lessons From Social History" (1983) 3 Oxford Journal of Legal Studies 155. See also J Brenner, "Nuisance Law and the Industrial Revolution" (1974) 3 J Leg Studies 403, to which McLaren's article is a response.

19 Ibid, 219. See more generally G Keeton, "The Twilight of the Common Law" (1949) 45 Nineteenth Century and After 230.

20 Ogus, Richardson and Burrows, Policing Pollution (Oxford, 1983), p 5ff.

21 Wade, 'Introduction', Dicey, Law of the Constitution, $\left(10^{\text {th }} \mathrm{ed}, 1959\right)$ ciii.

22 Teubner, above n 3, 396.

23 Bartrip and Burman, The Wounded Soldiers of Industry (Oxford, 1983).

${ }^{24}$ Eg B Pontin, "Tort Law and Victorian Government Growth: The Historio-graphical Significance of Tort in the Shadow of Chemical Pollution and Factory Safety Regulation" (1998) 18 Oxford Journal of Legal Studies 661.

25 Ogus, Regulation: Economic Form and Legal Theory (Oxford, 1994).

26 Ibid, 260: " 'Private' regulation is peripheral to the subject-matter of this book".

27 'Economics, Liberty and the Common Law', above n 1, 57. 
approach." ${ }^{28}$ More general are the numerous commentaries in which regulatory law is depicted as a hermetically sealed normative closure, abstracted from any significant context it may have in tort. ${ }^{29}$

One of the main growth areas in scholarship over recent decades has been the empirical study of the implementation of regulation 'on the ground'. Yet here, no less than elsewhere, the tendency to dismiss tort's relevance is marked. In Ross Cranston's well respected study of trading standards regulation, ${ }^{30}$ for example, the principal focus is on matters of statutory crime; civil law and procedure is addressed only in so far as it is the object of consumers' and officials' ignorance. ${ }^{31}$ In an occupational health and safety setting, the Robens Committee's findings concerning the possible effects of tort litigation on enforcement of ex ante control remain noted, ${ }^{32}$ but unexplored at an empirical level. ${ }^{33}$ In the context of rivers pollution regulation, Hawkins' canonical socio-legal analysis, Environment and Enforcement, ${ }^{34}$ unfolds within an exclusively criminal-administrative framework, absent the doctrinally strict protection by nuisance of riparian rights. When reading these accounts, it is as if Jeremy Bentham's ideal of legislation purged of common law fields such as tort is realised in the implementation of regulatory law, devoid of any common law, private law context. ${ }^{35}$

28 Ibid. However, Ogus did nonetheless suggest that the tension most "central to society" arises from the coexistence of "regulated and unregulated activity", although it is not clear that 'unregulated' is or should be understood as synonymous with common law, private law.

29 Consider in this connection Ayers and Braithewaite, Responsive Regulation: Transcending the Deregulation Debate (Oxford, 1992), which advocates a "mix of regulatory strategies" ( $\mathrm{p}$ 128) and proposes "that certain regulatory tasks might be delegated to private parties" (p 158) - without explicitly bringing to bear issues of tort. This begs the questions: 'haven't regulatory strategies always been mixed?'; And 'aren't regulatory tasks already performed by private parties?' $C f$ Ramsay, Consumer Protection: Texts and Materials (London, 1989); and below.

30 Cranston, Regulating Business: Law and Consumer Agencies (Oxford, 1979).

31 Ibid. There is a discussion of mediation as a discrete, non-criminal function, although this is deliberately cursory because it "mainly concerns civil law" (p 21).

32 Report of the Committee on Safety and Health at Work (Cm 5034, 1972). The Committee's terms of reference related principally to regulation aimed at accident prevention, but it was found impossible to ignore the "interplay between compensation arrangements and accident prevention arrangements" and, specifically, the "evidence of unfortunate effects from the former to the latter" (para 424). This is noted, but not empirically tested in Harris et al, Compensation and Support for Illness and Injury (Oxford, 1984).

33 There is indeed some research into the impact of accidents on enforcement of $e x$ ante regulation: B Hutter and S Lloyd-Bostock, "The Power of Accidents" (1990) 30 British Journal of Criminology 409. However, little reference is made to the relevance of tort; nor is there any attempt to test the findings of the Robens Committee on this point.

34 Hawkins, Environment and Enforcement: The Social Definition of Pollution (Oxford, 1983).

35 The place of a Benthamite ideal of regulation in socio-legal analysis is discussed in D Galligan, "Introduction" (1995) 22 Journal of Law and Society 1. Interestingly, the purging of common law as a characteristic of this ideal is not mentioned; the focus is instead on the idea of law being universal in its application, and unproblematic in terms of underpinning norms. This is perhaps a 


\section{BLACKSTONIAN AND BENTHAMITE IMAGES OF LAW}

The reference to Bentham immediately above is pertinent to the task of explaining the level of academic disengagement from the theme at hand. Together with Blackstone, Bentham can be understood to be at the forefront of an intellectual tradition in which common law and regulatory law are presented as mutually exclusive legal forms: to study one is necessarily to bracket-off the other. This section elaborates briefly on how the writing of each gives powerful expression to a polarised, and ultimately reductive account of law in this way. ${ }^{36}$ The belated engagement with a more heterogeneous view of the two interacting, which is the focal point of the discussion in subsequent sections, is in large part a reflection of the resilience of this reductive image of law.

With respect to Blackstone, it is well known that his Commentaries demonstrated a contempt for statute which cast a long shadow over legal scholarship for much of the nineteenth and twentieth centuries. ${ }^{37}$ Blackstone's idealisation of the importance of the judiciary in the eighteenth century legal system is behind the endurance of "an ancient tradition amongst judges that the common law is a superior form of creation to statute". ${ }^{38}$ His privileging of the 'artificial reason' of the common law helped ensure an academic pre-eminence for this legal form long after this was impossible to justify on practical grounds, when compared to the growing body of regulatory laws. ${ }^{39}$ In the mildest of terms, Blackstone's predilection for the common law invited little attention to issues of regulatory law context. Critically, there remains something of this 'common law centrism' in most law faculties, even today. ${ }^{40}$

It is also well established that Bentham, when faced with a similar legislative landscape to Blackstone, in which common law and statute coexisted in a

missed opportunity, in the sense that it is difficult to imagine a more profound challenge to Bentham's ideal of regulation than the coexistence alongside regulatory law of common law, private law provision such as tort. Indeed, to neglect common law tort is to risk reinforcing the very image of law that is the object of critique.

36 The term 'reductive' is important to this analysis. It denotes a doctrine or theory that reduces (whether explicitly or implicitly) the apparently more sophisticated and complex in a legal system to the less so. An illustration is provided by John Austin, The Province of Jurisprudence Determined, of which it has been said that the diverse forms of law in a common law jurisdiction are reduced to a criminal law model: see Hart, The Concept of Law, ( $2^{\text {nd }}$ ed, 1994), p 32.

37 Commentaries on the Laws of England, vol 1, (9 ${ }^{\text {th }}$ ed, 1783). See generally Twining, Blackstone's Tower: The English Law School (London, 1994). For an American perspective see Chase, The American Law School and the Rise of Administrative Government (Madison, 1982).

38 Zander, The Law-Making Process, (5th ed, 1999), p 125.

39 Consider in this connection Duxbury's remarks about American legal realism, as representing a critique of (Blackstonian) formalism that was unable to escape from the constraint that it imposed upon itself by continuing to rely on a (Blackstonelike) private law jurisprudence in an increasingly regulatory law world: Patterns of American Jurisprudence (Oxford, 1995), p 157-58.

40 Blackstone's is a "dominant English academic tradition", albeit one that has "never gone unchallenged": Twining, above n 37, p 3. 
highly haphazard manner, ${ }^{41}$ proposed a science of legislation: a science oriented around the institution of a reformed Parliament promulgating public, comprehensive, complete and prospective laws, guided by the principle of utility. ${ }^{42}$ Whereas Blackstone sought to cleanse the common law of the distortions caused by ad hoc, and unintegrated statutory intervention, ${ }^{43}$ Bentham sought the opposite. Bentham's is an ideal of law constructed profoundly in the image of statute. ${ }^{44}$ Thus Bentham and Blackstone, albeit from very different perspectives, arrive at a reductive view of law, whose legacy in modern writing represents a formidable obstacle to an understanding of common law and statutory sources and forms interacting.

This image of law is now evidently losing some of its grip. ${ }^{45}$ In its place is a greater willingness to take seriously some of the problems - and opportunities - presented by the fields interacting. Certain aspects of this intellectual shift can be traced to readily identifiable, concrete events, which have conspired to raise the profile of the theme. This is particularly true of the then Rules of the Supreme Court, Order 53, which altered the framework relating to the judicial treatment of the 'private/public divide' ${ }^{46}$ It is also true of an intriguing series of judgments concerning nuisance and negligence in the context of regulatory laws (notably Cambridge Water, Gillingham, Margereson and Hancock, and X v Bedfordshire CC), ${ }^{47}$ which make little sense within a Blackstonian or Benthamite frame of reference.

Less easy to locate in terms of an original moment is the "crisis in the post war welfare state", ${ }^{48}$ and the era of 'privatisation' that are the inescapable social and economic context of legal scholarship today. ${ }^{49}$ These are important societal developments, which call for a more sophisticated view of the

41 The historical context of Blackstone and Bentham's writing is thoroughly covered elsewhere: see in particular Holdsworth, A History of English Law, Vol 11 (London, 1938). It is however important to note that the eighteenth century legislature was weak and, with few exceptions, handed down little of major significance. Yet common law was by no means the only source of law of practical relevance. Statute law pervaded the legal system. Both private and local legislation proliferated: "statutes had many parents" (Holdsworth, p 371). These statutes were generally poorly drafted, with little or no regard for their consistency in relation to one another, or in relation to the common law.

42 Bentham, Introduction to the Principles of Morals and Legislation (Burns and Hart (eds), London, 1970). See the discussion in Lieberman, The Province of Legislation Determined (Cambridge, 1989). The substance of Bentham's critique of Blackstone, and the common law, is well documented, albeit that it is found in various guises throughout his work: Postema, Bentham and the Common Law Tradition (Oxford, 1986), p 268.

43 Blackstone, Commentaries, above n 37, p 27.

44 Similar remarks have been directed at Hart's Concept of Law, (2 $2^{\text {nd }}$ ed, 1994): see A W B Simpson, "The Common Law and Legal Theory" in Simpson (ed), Oxford Essays in Jurisprudence, ${ }^{\text {nd }}$ Series (Oxford, 1973) 303.

45 See above, n 2, 10-17, and associated text.

46 See J Beatson, “Public" and "Private" in English Administrative Law' (1987) 103 LQR 34; D Oliver, "Common Values in Public and Private Law and the Public/Private Divide" [1997] PL 630.

47 Outlined above, n 10-17 and associated text.

48 Eg Teubner (ed), Dilemmas of Law, above n 1 and “After Privatisation?", above n 3.

49 Ibid 
interrelationship between common law forms such as tort and regulatory law than is offered within a Blackstonian or Benthamite rubric. The complex, multi-dimensional debate that is opened up, and the issues arising, are discussed in the sections that follow.

\section{TORT AS A REGULATORY DEVICE: ITS SCOPE AND LIMITATIONS}

Students of tort are increasingly less likely to be introduced to this subject as one of the few common law fields to have withstood the proliferation of statutory regulation. It is now clear that areas of life once regulated or 'facilitated' by tort are today regulated under statute too. This is the point that Ogus was making when he criticised academic lawyers for their preoccupation with, for example, nuisance to the exclusion of pollution legislation. ${ }^{50}$ The adjective that Peter Weir uses in this connection captures well the potential complexity of the arrangement at the intersection of tort and regulatory law: statute does not simply tidy up or reform tort; statute is 'overlaid' in the form of regulatory law upon tort's freestanding provision. ${ }^{51}$

Against this backdrop, a number of issues arise for consideration. Issues that are already receiving some attention in this regard concern tort doctrine and, in particular, the resolution of the doctrinal confusion that characterises a public authority's liability in negligence, ${ }^{52}$ and nuisance. ${ }^{53}$ However, it is with issues of a broader theoretical nature that this section is concerned. For reasons which have been alluded to above, theoretical writing on this subject is comparatively underdeveloped. Yet exceptionally, there are pockets of legal theory concerning, notably, economic analysis of law, and also more overtly normative standpoints, which repay closer scrutiny for what they reveal of the scope and limits of tort in a regulatory law context. As a matter of emphasis, nuisance is selected as the principal tort medium through which to draw from these theoretical perspectives their main implications.

\section{Nuisance and Regulatory Law - An Economic Perspective}

Undeservedly overshadowed by recent literature in this field, notably that of Shavell, ${ }^{54}$ is Michelman's analysis of tort in "Pollution as a Tort: A NonAccidental Perspective on Calabresi's Costs". ${ }^{55}$ His analysis is one of the

50 Above, $\mathrm{n} 1$.

51 Weir, Casebook on Tort, (7 $7^{\text {th }}$ ed, 1992) p 2-3.

52 See above $\mathrm{n} 10$. Academic opinion is as divided as that of the courts, at least to the extent that there is a cogent academic justification for each of the three judicial approaches identified by Buckley, n 10, at 25-26. For example, Weir and Craig's articles cited above represent Buckley's two extremes, with Buckley himself putting forward a version of a more pragmatic middle ground.

53 Consider in this connection the opposing views on Gillingham et post of J Penner, "Nuisance and the Character of the Neighbourhood" (1993) 5 Journal of Environmental Law 1, and R English, "A Spot of Nuisance in the Docklands" (1996) 59 MLR 726.

54 S Shavell, 'Liability for Harm Versus Regulation of Safety' (1984) 13 J Leg Studies 357.

55 (1971) 80 Yale Law Journal 647. See Donald Dewees et al, Exploring the Domain of Accident Law (Oxford, 1996), for a discussion of some of the issues raised by Michelman in the context of more recent developments in civil liability. 
first serious, and still most comprehensive engagements of nuisance scholarship with its regulatory context. It is an adaptation of the framework developed by Guido Calabresi in The Costs of Accidents. ${ }^{56}$ As such it is 'instrumentalist', in the sense that it is concerned with the efficiency of different forms of law in allocating resources toward a given policy end. Whereas Calabresi is concerned with accidents giving rise to personal injury, Michelman is concerned with non-accidental pollution of the environment. Both, though, take as their fundamental concern the relationship between tort and regulatory law, accepting that neither on its own - in its purest form - is worth dwelling upon. In Michelman's case, this concern is reflected in an ambitious attempt at articulating a "proper niche for nuisance law in a total system [encompassing regulatory law]." 57 It thus demonstrates an awareness of wider legal context that Ogus rightly criticises much other economic analysis for neglecting. ${ }^{58}$

Michelman's analysis of "the coexistence of centralised and decentralised subsystems" 59 unfolds within a crude but familiar hypothetical scenario of a "smoke belching factory imposing costs on nearby residents". ${ }^{60}$ A pure market approach is dismissed on the grounds of transaction costs. Nevertheless, any centralised scheme which eliminates market allocation of pollution costs is considered equally inconceivable; a 'total' command-andcontrol system is simply a nonsense, as any form of regulatory law will inevitably leave some decisions to the market. Michelman takes as his exemplary centralised scheme one in which maximum allowable concentrations of pollutant are prescribed by a public agency. His attention then turns to the role that nuisance law may have in structuring the inevitable market transactions that the collective scheme will leave open. ${ }^{61}$ Two options are given particular attention. The first is to allow for actionability in nuisance so far as the interference with individual property rights is caused by emissions which are consented to, and in compliance with the consent. This has no obvious analogy in domestic law. The second is to render actionable only those interferences that arise out of emissions not consented to, or in breach of a consent. The analogy here is with the defence of

56 G Calabresi, The Costs of Accidents (New Haven, 1970).

57 Michelman, above $\mathrm{n} 55,666$. Michelman's focus on context is in striking contrast to other of the most influential economic-oriented nuisance analyses, which have addressed the question of what nuisance has to offer in the alternative to statutory regulation. Notable examples are: A I Ogus and G Richardson, "Economics and the Environment: A Study of Private Nuisance" (1977) 36 Cambridge Law Journal 284; D Dewees and Trebilcock, "The Efficacy of the Tort System and its Alternatives: A Review of the Empirical Evidence" University of Toronto, Law and Economics Working Paper Series 1 (1991); and G Calabresi and D Melamed, "Property Rules, Liability Rules and Inalienability: One View of the Cathedral" (1972) 85 Harvard Law Review 1093, which quickly established itself as an icon in the field, and did much to overshadow Michelman's discussion of issues arising from the context which tort and regulatory law provide for each other.

58 A I Ogus, "Corrective Taxes and Financial Impositions as Regulatory Instruments" (1998) $61 M L R$ 767. See above n 25 and 26 for the suggestion that Ogus himself is not immune from this criticism.

59 Michelman, above n 55, 675.

60 Ibid, 669 .

61 Ibid, 676 . 
statutory authority. A third option is also offered, allowing nuisance actions regardless of regulatory compliance. This option is not however discussed in any detail by Michelman. It is as if the issues which are raised by it are subsumed within the discussion of the first and second options.

With respect to the first option, Michelman posits circumstances in which centralised and decentralised schemes could interrelate beneficially. Actions for loss sustained in compliance with collective regulation might usefully 'backstop' those individual costs thought insignificant at a basin-wide level. ${ }^{62}$ Additionally, nuisance might serve as a 'private antenna' highlighting points at which public controls are weak. ${ }^{63}$ These roles are not however considered anything more than interstitial by Michelman. More serious are the potential tensions that this arrangement could engender, particularly the tension that would result were liability imposed in circumstances where the relevant regulatory standards had been "deliberately calibrated to allow some polluters to inflict some harm on some neighbours". ${ }^{64}$ Allowing individual recovery would "undercut the premises of the regulatory scheme". ${ }^{65}$ This is an important point, which will be returned to when considering normative analyses of tort's regulatory context.

Problems of a distinct nature arise from the second, statutory authority-like option. On the benign, mutually reinforcing side, actions for non-consented damage could help fill the gap left by "laggard enforcement". ${ }^{66}$ This positive contribution is more than offset however by problems of coordination and coherence arising from the introduction of private enforcers alongside public ones. ${ }^{67}$ More fundamentally, private enforcement of public standards would require of nuisance law a departure from its archetypal economic role as facilitator of private transactions. Nuisance in this context would become a vehicle for enforcing standards set elsewhere, beyond the private law framework, and potentially without the participation of the individual parties. Similar problems arise from the scope that exists for private nuisance being deployed to offset laggard standard-setting ${ }^{68}$ This would involve the courts in collective pollution cost appraisal; ${ }^{69}$ as such, it would require of the courts consideration of costs beyond those bound up with the polluter and receptor. This in turn would raise questions of the courts' competence in relation to regulatory authorities better suited to the task - questions of institutional integrity. ${ }^{70}$

62 Ibid.

63 Ibid. This is couched later by Dewees in terms of an "early warning system", serving to "identify and publicize" a pollution problem, "bringing it to the attention of the polluter and of the government": D Dewees (with Halewood), "The Efficiency of the Common Law: Sulphur Dioxide Emissions in Sudbury" (1992) 42 University of Toronto Law Journal 1, 21.

64 Ibid, 677.

65 Ibid. Precisely what premises Michelman is referring to here is not elaborated on by him, beyond, that is, general references to giving effect to the public interest by arriving at an economically optimal allocation of pollution.

66 Ibid.

67 Ibid.

68 Ibid, 679.

69 Ibid, 680

70 Ibid. For a fuller discussion see Coleman, Risks and Wrongs (Cambridge, 1992). 
Michelman's conclusions are, in certain respects at least, of less interest than the range of issues that inform his analysis; certainly, the depth of his contextual reflections has ensured that his essay has lost none of its initial topicality. One conclusion of utmost importance, however, concerns Michelman's emphasis on the gravity of the obstacles in the way of anything other than a peripheral role for tort. In particular, Michelman goes no further than envisaging a place for injunctive relief, and compensation, where emissions in breach of regulatory consent are responsible for interference with an individual's property rights. He comes down strongly against any broader role for nuisance in respect of, say, the determination of acceptable pollution standards, preferring such matters to be channelled into the enforcement of public law obligations by means of judicial review. By implication, he would object to Gillingham, Wheeler and Hunter, where regulatory standards prescribed by delegated bodies lack definitive force for purposes of nuisance. ${ }^{71}$ It is also worth adding that he would have difficulty with Margereson and Hancock, ${ }^{72}$ albeit that this is a negligence case, in which tort liability was imposed on the basis of an analogy with obligations in regulatory law. ${ }^{73}$ One final extrapolation from Michelman's analysis in this regard is the problematic effect of Barrett, ${ }^{74}$ whose relaxation of the 'exceeding-the-ambit-of-discretion' precondition of a duty of care laid down in $X \mathrm{v}$ Bedfordshire $C C$ (in favour of the application of Caparo simplicter) opens the way for tort to 'undercut the premises' of public law. In terms of Professor Buckley's analysis, then, Michelman would sit firmly within the first, 'sceptical' approach to tort liability. ${ }^{75}$

Many of Michelman's themes have subsequently been rehearsed in spheres beyond nuisance and pollution. An interesting example is Viscusi's economic analysis of product safety, which begins with an intriguing (and ambitious) attempt at quantification of the 'overlap' between tort and regulatory law: one statistic quoted in this vein is that of 19 per cent of tort claimants citing regulatory violations in their claims. ${ }^{76}$ More generally are the accounts of Shavell, ${ }^{77}$ Kolstad et al, ${ }^{78}$ and Rose-Ackerman, ${ }^{79}$ which are concerned with the task of articulating 'a complete solution' of the kind that will exploit the mutual benefits of tort and regulatory law interacting, ${ }^{80}$

71 Gillingham Borough Council v Medway (Chatham) Dock Co Ltd, above n 13. It may be presumed that the US position is more to Michelman's liking: See A Linden, "Strict Liability, Nuisance and Legislative Authorization", above n 9, 213 214.

72 Margereson, above n 10.

73 This case represents the much-maligned enforcement of standards prescribed (in part, at least) beyond the sphere of private law, without participation of the parties to the dispute.

74 Above n 11, 211h (per Lord Slynn of Hadley).

75 Above $n 10$.

76 W K Viscusi, "Product Liability \& Regulation: Establishing the Appropriate Institutional Division of Labour" (1998) 78 Am Econ Review 300 (P \& P).

77 Above n 54.

78 C Kolstad, T Ulen and G Johnson, "Ex Post Liability for Harm vs Ex Ante Safety Regulation: Substitutes or Complements?" (1990) 80 Am Econ Review 888.

79 S Rose-Ackerman, "Tort Law as a Regulatory System" (1991) 81 Am Econ Review 54 (P \& P).

80 Shavell, above n 54, 365. 
whilst avoiding their working at 'cross-purposes' ${ }^{81}$ Significantly, they all argue to the same conclusion as Michelman. Only in circumstances where regulatory law is unable to allocate risk optimally should it be supplemented by tort. In the vernacular of Kolstad et al, tort's functioning is profoundly parasitic on regulatory law's sub-optimality. ${ }^{82}$

\section{Tort and Responsibility}

The scope for tort 'compensating' for shortcomings in the regulatory framework is explored, from a different standpoint, by Jenny Steele. ${ }^{83}$ Steele argues that, putting to one side the transactional standpoint characteristic of economic analysis in favour of one that is more explicitly normative, the significance of tort in a regulatory context lies in its concern with determining matters of individual responsibility for harm. Tort is particularly significant in this respect for its providing a forum within which to subject $e x$ ante apportionment of risk of the kind that Michelman and Shavell et al refer to (when speaking of the regulatory calibration of pollution), to an assessment in terms of responsibility when risk manifests itself in practice, ex post. ${ }^{84}$

Economic analysts' comments regarding deliberately calibrated loss take on a new light when tort is viewed first and foremost as repository of principles for determining responsibility. At a mundane level, a number of practical issues arise concerning the relationship between the ex post (tortious) and ex ante (regulatory) apportionment of risk. In particular there is the problem of ascertaining whether the specific loss at issue in tort proceedings is of the kind that regulatory law has sanctioned or 'calibrated'. Where the relevant statute (or regulatory decision) is explicit on this point, the matter would of course be straightforward. However, such is the ingrained reluctance on the part of Parliament and Government to openly countenance risk of future loss or damage in these circumstances, it will be rare for intent on this score to be expressed..$^{85}$

More profound are the issues which arise concerning the significance (for tort) that is then to be attached to any regulatory sanctioning of the risk in question. Economic analysis is preoccupied with the dangers in terms of efficiency of a legal arrangement in which a regulator's seemingly authoritative determination concerning optimal risk carries no weight when the risk manifests itself in practice after the event, in the context of litigation. For Steele, however, this concern reflects an idealised, technocratic and

81 Rose-Ackerman, above n 79, 56.

82 Above, n 78, 889.

83 As part of a more general discussion of tort's contribution to apportioning responsibility in the context of a broad range of modern risk, and changing conceptions of appropriate regulatory form: J Steele, "Assessing the Past: Tort Law and Environmental Risk", above n 2.

84 Beck, Risk Society (trans. London, 1992); G Teubner, "The Invisible Cupola: From Causal to Collective Attribution of Ecological Liability" in Farmer and Murphy (eds), Environmental Law and Ecological Responsibility: The Concept and Practice of Ecological Self-Organisation (Chichester, 1994).

85 The temptation towards silence, and the difficulties arising, are well illustrated by case law concerning the actionability of breach of statutory duty: see Stanton, above $\mathrm{n} 7$. 
ultimately untenable vision of regulation, as free from vested interests and other political distortions. It downplays the attraction that tort will have to at least two 'classes' of litigant: those frustrated by the ex ante public law process, who feel that their concerns as to risk were not attributed the weight they deserved; and those seeking a legal forum that is better able than regulatory law to reflect changing notions of risk tolerability, and responsibility for risk manifesting itself in injury. ${ }^{86}$

In drawing attention to these blind-spots in the economic analysis of tort, Steele's analysis does not underestimate the importance of issues of constitutional legitimacy and institutional competence which suggest that tort should proceed cautiously in the shadow of regulatory law. For example, it is acknowledged that the electoral mandate of local planning authorities places serious constraints on the courts, in respect of their enforcement of private rights protected by nuisance. ${ }^{87}$ Nonetheless, it is important to have it said that the intersection of tort and regulatory law is of significance looked at from the standpoint of judging moral responsibility, and not merely efficiency. ${ }^{88}$ Indeed, Steele's analysis illustrates particularly well how what are weaknesses when viewed from an economic standpoint, are strengths when viewed from a standpoint that is more broadly normative.

\section{Overlapping Remedies}

Critics have argued that at root it is the very extent to which tort is concerned with individual responsibility that is the source of its main limitation, and which explains its precarious position vis-à-vis regulatory law. Not all injuries can be traced to an individual cause, much less individual culpability. Even where they can, the cost of the process of doing so may be disproportionate to the benefits derived by society. This criticism is most often levelled against negligence, which is argued to be a drain on scarce resources: resources that could be better deployed giving more modest but nevertheless adequate security against misfortune, through public (and private) schemes set up to cover the broadest possible range of contingencies. ${ }^{89}$ Ideologically and instrumentally, negligence is understood to be a bankrupt system. If it is not "to be swept away in favour of a more rational, needs based system of comprehensive compensation", 90 it must at least be left to wither, as its appeal becomes ever more suspect in the face of growing awareness of alternatives. ${ }^{91}$

86 Steele, "Assessing the Past", above n 2.

87 J Steele and T Jewell, "Nuisance and Planning" (1993) 56 MLR 568, 569.

88 Here, perhaps, is the answer to the economic analyst's search for reasons behind tort's continuing attraction, inefficiencies notwithstanding: see eg RoseAckerman, above n 79, 55, who concedes that "widespread support for the tort system persists even when the logic of efficient risk control demands ex ante regulation" Steele's account offers a helpful normative explanation for this - in economic terms - inexplicable state of affairs.

89 For example Patrick Atiyah, Accidents, Compensation and the Law (London, 1970); Ison, The Forensic Lottery (London, 1967).

90 These are Jane Stapleton's words, in giving expression to the 'rationalist' standpoint within tort criticism: Stapleton, Product Liability (London, 1994), p 3.

91 Calabresi, above n 56, p 317. 
Indeed, the metaphor of withering sits comfortably with many historical accounts concerning the co-evolution of negligence and measures of the welfare state. Scholarship draws liberally from the Report of the Royal Commission on Civil Liability and Compensation for Personal Injury (Pearson Report) on this point, regarding social security. ${ }^{92}$ The "two systems have for too long been permitted to develop in isolation from one another". ${ }^{93}$ The result is, in the words of Harris, a "patchwork quilt" of "assorted compensation schemes": 94 a product of "unplanned, incremental change as politicians react to particular crises". ${ }^{95}$ However, the 'rationalist's' case against negligence is not heavily dependent upon historical analysis. It is not that tort and 'welfare state' provisions are inadequately dovetailed that is always the crux of the criticism; rather, it is that they are permitted to coexist alongside each other at all. ${ }^{96}$ Because of the profound differences between the two systems to do with the underlying contrast between individualism and collectivism, no amount of careful design will make up for what is understood to be an inherent irreconcilability. For critics, here, tort and welfare provisions are necessarily at the expense of one another.

Many of these considerations would appear to extend by way of analogy to the nuisance context. However, the call for rationalisation in this context is not heard to anything like the same extent that it has been in the context of negligence, if it has been heard at all. Well before the controversy either side of the Pearson Report, Glanville Williams predicted an increasing reliance upon administrative schemes where previously tort law had reigned. ${ }^{97}$ Intriguingly, Williams singled out environmental law as an area in which the shoots of this transition were already evident. ${ }^{98}$ That is to say, the practical ambit of nuisance was understood to be in the process being superseded by that of public regulation. With the passage of time, it is clear that any prophesied or willed transition from a private to a regulatory law system of remedies has not been borne out: this much is illustrated by the continuing controversies surrounding the relationship between nuisance and town planning. ${ }^{99}$ No less than negligence, then, nuisance falls to be discussed in

$92 \mathrm{Cm} 7054$ (1978).

93 Ibid, para 271.

94 D Harris, "Tort Law Reform in the United States" (1991) 11 Oxford Journal of Legal Studies 407, 412.

95 Ibid. Nevertheless, other writing suggests that it is possible to exaggerate the extent to which tort and welfare legislation have in fact evolved in isolation. For Conaghan and Mansell, "the question how far the social security system should extend and assume responsibility for what has traditionally been the province of the tort system has never been far from the surface of debate about the nature and scope of the welfare state": The Wrongs of Tort (London, 1993) p 96. For Bartrip and Burman, turn-of-the-century common law continued to hold considerable attraction to employees notwithstanding the enactment of statutory measures of workers' compensation, above $\mathrm{n} 23$.

96 R Abel, “A Socialist Approach to Risk" (1982) 41 Maryland Law Review 699.

97 G Williams, "Aims of the Law of Torts" (1951) 4 Current Legal Problems 137, 174.

98 Ibid.

99 See Gillingham Borough Council v Medway (Chatham) Dock Co Ltd; Wheeler v Saunders; Hunter v Canary Wharf (CA), above n 12. For commentary see J Steele and T Jewell, "Nuisance and Planning" (1993) 56 MLR 568; Steele, "Private Rights and Planning Consent" [1995] Web Journal of Current Legal Issues; S 
terms of its coexistence alongside remedies of a public law, regulatory character.

If an explanation is needed for the lack of a rationalist voice speaking out against overlapping remedies in a nuisance context it might lie in the sense in which certain of the most high profile regulatory law remedies are privatised rather than collective: ${ }^{100}$ that there is not the ideological clash that might have appeared at the level of negligence and social security. However, this explanation is not convincing, because social security is now itself showing signs of increasing privatisation, without thereby detracting from the interest of its interaction with tort. ${ }^{101}$ Alternatively, the explanation for the lack of a rationalist voice in a nuisance context may be more mundane. Statutory powers of an ex post character to do, for example, with environmental remediation have only recently begun to attract academic attention. Meanwhile, rationalism has lost much of the momentum that it had at its height in the 1960s and 1970s. ${ }^{102}$ Given too the parochial nature of the rationalists' case when at its most influential (focused heavily on the tort of negligence), it is easy to appreciate how developments in respect of nuisance have received less discussion in terms of this standpoint than they might otherwise merit.

\section{Scope and Limitations}

One important (if trite) problem in the way of any assessment of these economic and normative perspectives is the lack of pertinent empirical evidence. Despite the high profile of research that has been published in the field of personal injury, there remains a considerable amount still to be learnt about the interaction of tort and regulatory law in practice. An encouraging development in this respect is the recent study of the effects of common law, civil liability on local authorities in exercising their statutory functions, ${ }^{103}$ which could be usefully extended to cover a wider range of regulatory settings. High on any list of priorities in this regard must be to test the empirical basis of the competing policy claims invoked by the courts, in determining public authority liability in negligence: ${ }^{104}$ is Lord Hoffman right

Ball, "Nuisance and Planning Permission" (1995) 7 Journal of Environmental Law 290; R English, "A Spot of Nuisance in the Docklands", above n 53; Steele, "Assessing the Past", above $\mathrm{n} 2$.

100 T Jewell and J Steele, "UK Regulatory Reform and the Pursuit of "Sustainable Development": The Environment Act 1995" (1996) 8 JEL 283, with particular reference to liability for contaminated land remediation.

101 The uncertain future of tort in the context of first party insurance is discussed by $P$ Atiyah, "Personal Injuries in the Twenty First Century: Thinking the Unthinkable" in Peter Birks, (ed), Wrongs and Remedies in the Twenty-First Century (Oxford, 1996).

102 Symbolised, for example, by the decline of the New Zealand no-fault compensation scheme: Markesinis and Deakin, Tort Law, (3rd ed, 1994), p 5-6.

103 James George, "Responsible Regulation? The Effects of Liability on Regulatory Enforcement", paper given to the Annual Conference, Socio-Legal Studies Association, 1 April 1996.

104 For an indication of the range of policy factors, see those weighed in by the defence - and dismissed by the Court of Appeal - in Capital and Counties Plc, above $n$ 17, at 352-58. These are (1) no improvement in the standard of care of public authorities liable in tort; (2) inducing defensive practices; (3) private 
to assert in Stovin that common law liability will inevitably distort the priorities of regulatory bodies?: ${ }^{105}$ or is the better view that of Lord Slynn in Barrett, who envisages that liability may have a beneficial effect on regulatory good practice? ${ }^{106}$

Another potentially fruitful line of empirical enquiry would focus on the comparatively neglected tort of nuisance where, at present, fieldwork has tended to confine itself to evidence of the costs of bringing a nuisance action. ${ }^{107}$ This only scratches at the surface of the problem of finding a niche for this tort in a broader regulatory context. Large gaps are left concerning, notably, the extent to which public regulators are reliant upon - or undermined by - individuals unilaterally utilising freestanding tortious routes for protecting private rights. The doctrinally 'coercive' edge of nuisance, ${ }^{108}$ by which this tort attaches itself to the lawfulness of a given outcome (more than a decision making process), adds further interest to any prospective empirical research in this field.

Even assuming a fuller range of empirical information, however, it is clear from the foregoing analysis that much depends on the standpoint from which tort's relationship with regulatory law is analysed. This point is vividly illustrated by the comparison between Michelman and Steele. What is for one commentator a grave risk to efficiency arising from tort's interaction with regulatory law is, for another, a valuable counter-current to regulatory law's biases, conferring overall legitimacy on a regulatory regime which would otherwise be lacking were matters left to regulatory law alone. This problem of standpoint is compounded by rationalist thought which, on normative grounds, would see tort replaced by less individualistic alternatives. Empirical research, then, would need to be sophisticated enough to do justice to the full range of competing theoretical accounts of tort's relationship with regulatory law.

On balance, Steele's analysis would appear to have the most to commend it. This is because it is able to accommodate economistic concerns with efficiency and effectiveness, without at the same time being dependent on unrealistic, over-reductive assumptions regarding economic rationality and, in Michelman's case, apolitical regulatory decision-making. It is also free from the commitment to purely collective solutions to compensation problems of rationalists, support for which has dwindled somewhat since the groundbreaking work of Ison and Atiyah. ${ }^{109}$ This provisional conclusion will be returned to later, once having situated this and other aspects of tort scholarship in the broader philosophical context of differing legal rationalities (transcending tort). Debate here is at the heart of the 'is's' and 'shoulds' of tort's interaction with regulatory law.

litigation being unsuitable for discovering failures of service; (4) undesirability of actions against authorities operating for collective welfare; (5) floodgates; (6) distraction from primary public service; (7) massive claims against the taxpayer; (8) Insurance.

105 Stovin, above n 17 at 958B.

106 Barrett, ibid at 208F.

107 Dewees and Trebilcock, above n 57.

108 Steele, "Private Law and the Environment", above $\mathrm{n} 2$.

109 Above n 89. 


\section{THE PROBLEM OF INTERACTING LEGAL RATIONALITIES}

Common law private law and regulatory law have long been associated with distinctive modes of legal rationality. These are perhaps most familiar in the context of Blackstone and Bentham, in whose writings the modes at issue concern the 'artificial' or 'common' reason of the common law, ${ }^{110}$ and the utilitarian, fundamentally instrumental mode of rationality reflected in Bentham's ideal of codified law. ${ }^{111}$ However, neither writer gave any serious attention to the interaction of these modes of rationality and, in particular, the extent to which they are compatible or mutually reinforcing. Theirs are reductive accounts, in which is expressed the supremacy of one legal rationality over the other.

\section{Weber and Hayek}

A similar observation can be made of the influential early twentieth century work on the part of Max Weber and Frederick von Hayek. With respect to Weber, it is significant that his concerns were first and foremost those of a civilian law scholar: his famous distinction between 'formal rationality' and 'substantive rationality' corresponds closely to continental processes of codification and decodification. ${ }^{112}$ As a consequence, there is little in Economy and Society that speaks explicitly to issues of rationality within a common law jurisdiction. Whilst Weber probably shares many of Bentham's doubts about common law having any claim to rationality, ${ }^{113}$ common law is left largely unexamined, as a complex of "deviations, exceptions and marginal notes." 114 Perhaps more significant is Weber's silence regarding the prospect of distinctive rationalities interacting in a civilian law setting. ${ }^{115}$ His is a gloomy analysis of the inexorable domination of substantive rationality reflected in regulatory law, over formal rationality embodied in the code. ${ }^{116}$ The upshot, therefore, is that Weber reinforces the reductive image of law given effect in the work of Blackstone and Bentham.

Hayek, unlike Weber, directed his concerns squarely at common law's rationality vis-à-vis regulatory law. ${ }^{117}$ Thus it is in the setting of a common law tradition that his pivotal distinction between 'spontaneous order' and 'rational constructivisim' is explicitly situated. The spontaneous order is evolutionary in nature. It is characterised by the instinctive, or spontaneous, adoption of often unformulated rules. Though enforced, these rules are not designed. As with Weber's 'formal legal rationality', the rules of Hayek's 'spontaneous order' are pitched at a high level of generality. However, unlike

110 See S Milsom, "The Nature of Blackstone's Achievement" (1981) 1 Oxford Journal of Legal Studies 1.

111 See Postema, above n 42.

112 Weber, Economy and Society, vol 2 (trans. London, 1978) 641ff and 880ff; Merryman, The Civil Law Tradition (Stanford, 1985), p 151.

113 Murphy, The Oldest Social Science? (Oxford, 1998), p 82ff; also D Sugarman, 'In the Spirit of Weber: Law, Modernity and "The Peculiarities of the English", (Wisconsin Working Papers in Legal History, 1987).

114 Ibid, 83

115 But $c f$ Murphy, ibid 40.

116 Ibid, 41

117 References to Hayek here are to Law, Legislation and Liberty, vol 1 (London, 1973). 
either of Weber's notions of rationality, rules of the 'spontaneous order' have an organic quality that does not presuppose a sovereign command. ${ }^{118}$ In practical terms, its legal reflection is in the common law, including tort.

By contrast, 'rational constructivism' is reflected in regulatory law. This mode of rationality is purposive, and typically lacks the generality of rules of the spontaneous order. It shares many of the most significant features of Weber's substantive legal rationality, notably an instrumentality that sees law harnessed under sovereign authority to the pursuit of typically factional social objectives. It also shares a normatively problematic status: for 'formal rationality' in Weber read the privileged 'spontaneous order' in Hayek. Both writers, then, present a vision of a pathological dualism, in which each of the opposing legal rationalities is irreconcilable with the other. Subject to the qualification immediately below, this forestalls serious contemplation of a heterogeneous order in which the two interact.

It has already been noted elsewhere ${ }^{119}$ that Hayek's allegiance to the rationality of the common law did not blind him to the scope for legitimate statutory intervention. For example, he envisaged that statute could and should intervene to anticipate what would otherwise be an inordinately slow development in the spontaneous order. ${ }^{120}$ In this respect statute would assume a role in mimicking the common law. Another role for statute in this regard is on occasion of judicial error, or even bias. ${ }^{121}$ In neither instance, however, could statute's role be said to be anything more than secondary. This calls to mind Bentham's remark, directed at Blackstone, that "the employment of the legislator is not so sad a one" as to be confined to mere guardianship of the integrity of the common law. ${ }^{122}$ Hayek's concessions to statutory intervention fail to explain the continued vitality of freestanding, autonomous regulatory forms (for example in fields such as town and country planning, environmental protection and the like). His account, though helpfully focused on the common law, lacks both a convincing explanation of, and justification for, legal rationalities interacting.

\section{Systems Theory: Tort, Regulatory Law and 'Polycontexturality'}

Perhaps the most sustained treatment of the interaction between differing modes of legal rationality is found in the systems theoretical writing of Gunther Teubner. ${ }^{123}$ Of particular interest in this respect is his account of rationality in the context of "post-privatisation". ${ }^{24}$ His adaptation of

118 See Murphy, above n 113, for a discussion of the role of sovereignty in Weber's writings.

119 A I Ogus, "Law And Spontaneous Order: Hayek's Contribution to Legal Theory" (1989) 16 Journal of Law and Society 393, 397.

120 Hayek, above n 117, p 88.

121 Ibid, p 89.

122 Comment on the Commentaries (1977), p 138.

${ }^{123}$ For an accessible introduction to 'systems theory' see Loughlin, Public Law and Political Theory (Oxford, 1992), pp 250-59.

124 Teubner, above n 3, 393. 'Privatisation' refers to the introduction of market structures into governance. Speculating on 'post-privatisation' involves considering the opportunities for an introduction of broader social and ethical values. 
Gotthard's neologism "polycontexturality", ${ }^{125}$ which denotes a post-modern mode of rationality characterised by a spontaneous bringing to bear of multiple perspectives (economic, political and social), advances the discussion considerably. It offers a promising route away from the dualistic, reductive writings of Weber and Hayek, and Blackstone and Bentham before them. The remainder of this section explores the extent to which Teubner's analysis realises its promise in relation to the theme at hand.

Teubner's main argument for present purposes is that private law generally, and its common law incarnation in particular, have a privileged position in connection with polycontextual rationality. This is primarily because common law has what Teubner describes as an "elective affinity" with the "contemporary plurality of discourse", which enables it to legally embody or "juridify" the spontaneous norm formation that is critical to polycontexturality. ${ }^{126}$ Pre-eminent among its qualities in this respect is a unique capacity for "responsiveness" to signals emanating from a multiplicity of economic, political and social systems. ${ }^{127}$ One example is taken from tort: the rejection of the economistic 'Learned Hand formula' in US negligence law. ${ }^{128}$ Clearly, however, for purposes of assessing the cogency of Teubner's vision, it is necessary to have recourse to a far fuller range of tort authorities.

A closely related notion of Teubner's that needs to be considered for its practical application in the context of the theme at hand is that of legal "hybridisation". 129 This is a corollary of common law private law's responsiveness, noted above. A hybrid arrangement is one in which common law private law allows itself to be informed by the political and economic interests or systems that are embodied in regulatory law, without thereby subjugating its autonomy. Teubner goes to some lengths to distinguish hybridisation in this rather opaque sense from more popular ideas of the 'fusion' of legal rationalities, for which he has little time. ${ }^{130}$ The crux of what he is suggesting in this regard appears to lie in the difference between a complex interplay of the competing demands of economic, political and social systems on the one hand (hybrid), and on the other, a blurring, or even resolution of system tensions (fusion). This is consistent with Teubner's familiar critique of the metaphysical ideal of a unified order, underpinned by

125 G Gotthard, "Life as Poly-Contexturality" in Gunter (ed), Beitrage zur Grundlegeng einer operationsfahigen Dialektik I (Hamburg, 1976). See Teubner, ibid, $396 \mathrm{ff}$.

126 Ibid, 396, 399. It is striking that Hayek's lexicon courses throughout Teubner's analysis ( $e g$ spontaneous norm formation), albeit, as will be seen, to different effect.

127 Regulatory law, in contrast, is too heavily grounded in the political system to observe and respond to developments elsewhere, ibid, 396.

$128 \mathrm{Ibid}, 422$. The 'Learned Hand formula' refers to an economic-oriented test to determine negligence liability laid out in Conway v O'Brien, $111 \mathrm{~F} 2 \mathrm{~d} 611,612$ (2d Cir 1940). According to this test, liability depends on: (1) the probability that the accident will occur, (2) the gravity of the resulting injury, and (3) the burden of adequate precautions.

129 Ibid, 396-97, and 419ff.

130 There "is [no] fusion of private and public law as suggested by such seductive slogans as "private life is public" or "everything is politics" " (ibid, 397). 
a grand system that transcends specific system differentiations. ${ }^{131}$ In Teubner's scheme, system differences are not resolved, but reconfigured.

Examples from tort which can be weighed in in support of Teubner's arguments include Hunter. This case suggests that private law is being deployed as part of what Teubner would view as a multi-dimensional strategy of public and private interest litigation, encompassing judicial review, and litigation before the (now defunct) European Commission on Human Rights. ${ }^{132}$ Perhaps more significantly, Hunter illustrates a demand being placed on tort to take a partisan stance against (what Teubner diagnoses as) the dominance of economic and political systems, as reflected in the regulatory law of town planning. ${ }^{133}$ These matters converge in the plaintiffs' successful argument in the Court of Appeal that compliance with planning consent for fast track urban regeneration should not confer immunity in private nuisance (as per the defence of statutory authority). ${ }^{134}$ In this way, tort may serve to challenge judgments as to risk, or policy priority more broadly, arrived at seemingly authoritatively within the rubric of regulatory law. ${ }^{135}$

In a similar, corroborative vein is Cambridge Water ${ }^{136}$ and Blue Circle Industries Plc v Ministry of Defence, ${ }^{137}$ where issues of regulatory context are integral to the definition of damage that is actionable in nuisance. These cases demonstrate tort's 'responsiveness', in drawing from the provisions of regulatory law, and factoring them into the process of common law reasoning. Perhaps most telling in this respect, however, is the role of health and safety regulation in supplying part of the rationale for imposing a common law duty of care in Margereson. ${ }^{138}$ This case exemplifies as well as any the 'hybridisation' of autonomous legal forms that is a feature of polycontextural rationality. ${ }^{139}$ It demonstrates how tort may take cognisance of regulatory laws, without being beguiled by the economic and political

131 See in particular Teubner, "Altera Pars Audiatur: Law in the Collision of Discourses", in Rawlings (ed), Law, Society and Economy (Oxford, 1997).

132 Khatoun and 180 others $\mathrm{v}$ UK (1998) 26 EHRR CD212

133 Above n 3, 421. The use of the language of 'partisan stance' here owes much to the sense in which systems theory does not allow Teubner to presuppose a unified system that transcends specific legal, political, economic (etc) system differentiations, such as to resolve conflicts between them. Instead, Teubner looks to alternative ways for systems to communicate with each other. More specifically, he highlights the scope for traditionally marginalised social or cultural systems making themselves heard in ways which disturb and disrupt the privileged position of dominant economic and political systems. See too "Altera Pars Audiatur", above n 131.

134 Hunter followed Wheeler and Gillingham in this respect, above $\mathrm{n} 40$.

135 Steele, "Assessing the Past", above n 2.

136 Above $n 11$

137 Above $\mathrm{n}$ 12: in particular is the recognition in Blue Circle that "given the sophistication of the regulatory systems now covering most areas of human activity, the views of regulatory authorities are often critical [to liability in nuisance]", (per Carnwath J).

138 Margereson above $\mathrm{n} 11$.

139 Teubner, above n 3, 419ff. 
influences which typically render them arbitrarily narrow in ambit (and apt for extension)..$^{140}$

Equally pertinent, however, are facets of these cases which suggest that there are important constraints on tort's responsiveness. In Hunter, ${ }^{141}$ the House of Lords refused to extend standing to sue in private nuisance beyond those with a direct proprietary interest in the land affected. In this way, the courts have declined requests to harness tort to broad and inclusive community interests of the kind that Teubner singles out as an important indicator of responsive, polycontextural law. ${ }^{142}$ In Cambridge Water, ${ }^{143}$ the House of Lords deferred to the legislature the task of advancing nuisance doctrine into the realm of strict liability, as championed by Teubner elsewhere. ${ }^{144}$ These cases cast in a different light Teubner's prediction that common law will come to reflect polycontexturality "with or without the support of the legislator"; 145 more to the point is the doubt that 'support' will be lent by the judiciary. ${ }^{146}$

In assessing this systems theoretical analysis, it should be stressed that Teubner is under no illusions as to the difference between conceptual opportunity and concrete legal development. For example, he voices doubts about common law's "conceptual readiness. . . to take advantage of the opportunities offered by [nascent] social structures". ${ }^{147}$ The case law touched on above suggests that he is right to do so. It reflects a deeply entrenched view of the division of labour between courts and legislature that depicts the latter's job as responding to change (the former's job being to promote stability). ${ }^{148}$ Taken together with the doctrine of precedent, of which Teubner is somewhat dismissive, ${ }^{149}$ it is clear that there are considerable obstacles in

140 Steele and Wikeley, above n 11, 270; N Wikeley, "Turner and Newall: Early Organizational Responses to Litigation Risk" (1997) 24 Journal of Law and Society 252.

141 [1997] 2 WLR 684 (HL).

142 Above n 3, 424 (with specific reference to contract).

143 [1994] 2 AC 264.

144 Teubner, "Invisible Cupola", above n 84. See in a similar vein Southwark LBC v Tanner; Baxter v Camden LBC [1999] 3 WLR 939 - a land law and nuisance case in which the House of Lords were reluctant to impose an obligation on local authorities to soundproof their premises, in the absence of any statutory provision to that effect. Problems concerning local authority allocation of resources were "best resolved by the democratic process. . . judges are not equipped to resolve them" (per Lord Millett, at 961).

145 Teubner, above n 3, 414.

146 Teubner can be criticised for his failure to address the problem of the limits of adjudication, as articulated by L Fuller, "The Forms and Limits of Adjudication" (1978) 92 HLR 353. Polycontextural rationality bears a significant resemblence to Fuller's exposition of polycentric disputes, defined in terms of their nonsuitability for judicial resolution. See further, J W F Allison, "The Procedural Reason for Judicial Restraint" [1994] PL 452.

147 Ibid, 419.

148 See generally Zander, above n 38.

149 Teubner makes no reference to stare decisis in his account. This calls to mind Murphy's suggestion that the impact of the doctrine of precedent may be too easily exaggerated: Murphy, above n 113, p 84. This is perhaps a fair point as far as it goes, although it should not detract from the constraints that the doctrine clearly continues to bring to bear. 
the way of tort realising the potential for thriving in a post-privatised society that Teubner contemplates.

Thus in the final analysis, there are evident mismatches between notions of polycontextural rationality and associated concepts, and trends in tort case law. They constitute serious problems for the explanatory aspirations of Teubner's account. Judgments in Cambridge Water and Hunter suggest that there are too many prominent instances of the courts deferring to the legislature, or precedent, to be confident that in a common law context at least, tort is as responsive as Teubner would suggest. However, from a more normative perspective, Teubner's thesis has much to commend it. ${ }^{150}$ It complements well the analysis of Steele, the value of which was discussed in the previous section. Most importantly, it contains the beginnings of an overarching theoretical explanation of distinctive rationalities interacting, of the kind that is lacking in legal theory in the aftermath of Blackstone and Bentham, and Weber and Hayek. It is not the last word; but it does nevertheless call for a considered response from other legal theorists, who lack an account of the type of society in which tort and regulatory law beneficially coexist, and the principles that should govern their interaction.

\section{CONCLUSIONS}

Tort continues to defy those who anticipated that it would now have withered in the shadow of more efficient and effective alternatives. Far from being superseded by regulatory laws, tort can be seen to be interacting with them. This has led some commentators to reconsider the relationship in question as having the capacity to be mutually reinforcing, rather than being (as traditionally conceived) mutually exclusive. Michelman was the first to express this point from the standpoint of economic analysis of law, although it is clear that for him and subsequently other economic theorists (notably Rose-Ackerman, Kolstad et al and Shavell), tort is ultimately parasitic on prior inefficiencies in the framework of regulatory law. Steele, with a more explicitly normative emphasis, envisages tort as a powerful counter-current to regulatory law, lending a legitimacy that would otherwise be lacking were decisions affecting risk left entirely to the law of regulation. In a more philosophical but complementary vein, Teubner understands tort, like any other field of private law grounded in spontaneous norm formation, to be better placed than regulatory law to bring to bear the full range of economic, political and social considerations that inform decisions under conditions of 'post-privatisation'. On these accounts, tort is neither replaced by, nor a replacement of, regulatory law; each are, and should continue to be profoundly interacting.

All this opens up a number of issues concerning the 'is' and 'ought' of the theme, which would benefit from further research. Historically speaking, it is worth putting forward for testing the hypothesis that tort's interaction with emerging regulatory forms was an important feature of the legal system during the industrial revolution, to an extent that is not fully conveyed by existing research focusing on occupational health and safety and pollution.

150 Even if its comprehensibility is somewhat compromised by the mixing of civilian and common law traditions, and its liberal recourse to neologism. 


\section{Northern Ireland Legal Quarterly [Vol. 51, No. 4]}

From a more contemporary perspective, it is imperative to attain a better grasp of the practical consequences of imposing tort liability in a regulatory setting and, in particular, to substantiate Lord Slynn's prima facie compelling view in Barrett $\mathrm{v}$ Enfield that liability in this context is, broadly, a force for the good. Perhaps most fundamental, however, is the need for this field to be better grounded philosophically. In this respect, some encouragement is to be had from the now extensive literature inquiring into the philosohpical foundations of negligence and nuisance in abstractu. ${ }^{151}$ The challenge ahead, then, is to build into this literature the missing contextual dimension, concerning tort's intersection with regulatory law.

151 Eg D G Owen, "Why Philosophy Matters to Tort Law", in Owen (ed) The Philosophical Foundations of Tort Law (Oxford, 1995), p 2-6. 